\title{
Modification of genetic regulation of a heterologous chitosanase gene in Streptomyces lividans TK24 leads to chitosanase production in the absence of chitosan
}

\author{
Marie-Pierre Dubeau, Isabelle Guay, Ryszard Brzezinski
}

\begin{abstract}
Background: Chitosanases are enzymes hydrolysing chitosan, a $\beta-1,4$ linked D-glucosamine bio-polymer. Chitosan oligosaccharides have numerous emerging applications and chitosanases can be used for industrial enzymatic hydrolysis of chitosan. These extracellular enzymes, produced by many organisms including fungi and bacteria, are well studied at the biochemical and enzymatic level but very few works were dedicated to the regulation of their gene expression. This is the first study on the genetic regulation of a heterologous chitosanase gene (csnN106) in Streptomyces lividans.

Results: Two S. lividans strains were used for induction experiments: the wild type strain and its mutant ( $\Delta c s n R)$, harbouring an in-frame deletion of the $\operatorname{cs} n R$ gene, encoding a negative transcriptional regulator. Comparison of chitosanase levels in various media indicated that CsnR regulates negatively the expression of the heterologous chitosanase gene csnN106. Using the $\triangle c s n R$ host and a mutated csnN106 gene with a modified transcription operator, substantial levels of chitosanase could be produced in the absence of chitosan, using inexpensive medium components. Furthermore, chitosanase production was of higher quality as lower levels of extracellular protease and protein contaminants were observed.
\end{abstract}

Conclusions: This new chitosanase production system is of interest for biotechnology as only common media components are used and enzyme of high degree of purity is obtained directly in the culture supernatant.

\section{Background}

Chitosan, a partly $\mathrm{N}$-deacetylated form of chitin, is naturally found in the cell walls of fungi, especially in Zygomycetes (Mucor sp., Rhizopus sp.), and in the green algae Chlorophyceae (Chlorella sp.) [1-3]. Chitosan, is a polysaccharide made of $\beta$-1,4-linked D-glucosamine (GlcN) units with a variable content of $N$-acetyl-D-glucosamine units. Chitosan is produced at industrial scale by alkaline deacetylation of chitin, originating mainly from crustacean shells [4]. This polysaccharide, almost unique among natural polymers for its amino groups that remain positively charged in mild acidic solutions, is the subject of numerous works oriented towards its

\footnotetext{
* Correspondence: ryszard.brzezinski@usherbrooke.ca

Centre d'Étude et de Valorisation de la Diversité Microbienne, Département de Biologie, Faculté des Sciences, Université de Sherbrooke, 2500 boulevard de I'Université, Sherbrooke, J1K 2R1, (Québec) Canada
}

numerous emerging applications in medicine, agriculture, dietetics, environment protection and several other fields [5-7]. Chitosan is also a valuable source of GlcN, a neutraceutical used as a therapeutic agent in osteoarthritis [8]. Many properties of chitosan, especially in biological applications are dependent on its molecular weight, i.e. on its degree of polymerization. The very short derivatives of chitosan - the chito-oligosaccharides are of particular interest, due to their increased solubility in aqueous solutions and their specific biological activities $[9,10]$.

To obtain chitosan chain of varying degrees of polymerization, several chemical and physical techniques were investigated [11-13]. Enzymatic techniques with either free or immobilized chitinase or chitosanase enzymes are also intensively studied [14-16]. Chitosanase production has been found in many microorganisms,

\section{() Biomed Central}


bacteria or fungi. The enzymes so far characterized at the primary sequence level belong to seven families of glycoside hydrolases: GH3, GH5, GH7, GH8, GH46, GH75 and GH80 [17-24]. While these enzymes are endo-hydrolases, their mechanism could potentially be transformed into exo-type by protein engineering as shown for the GH46 chitosanase from Bacillus circulans MH-K1 [25]. Chitosan can be also hydrolyzed by enzymes acting by an exo-mechanism generating GlcN monomers [26,27]. The chitosanases from Streptomyces have been widely studied in various aspects of structure-function relationships [28 and references cited herein]. Usually, these chitosanases are produced in the heterologous host Streptomyces lividans via the multi-copy vector pFD666 [29]. However, very few works have been dedicated to the regulation of chitosanase gene expression in the native and/or heterologous hosts. Most studies were limited to the follow up of chitosanase production in various culture media $[30,31]$.

The present report is the first study dedicated to the optimization of gene expression of a chitosanase in a heterologous host. The chitosanase gene under study, csnN106 has been cloned from the Kitasatospora sp. N106 strain (formerly Nocardioides sp. N106) [32]. The chitosanase CsnN106 is highly similar to other GH46 family chitosanases at the structural and biochemical level [33]. The strain N106 was among the most active chitosanolytic strains isolated through an extensive screening of soil samples [32,34].

In our previous work we observed that an efficient production of CsnN106 chitosanase in Streptomyces lividans TK24 was strictly dependent on the addition of chitosan or its derivatives to the culture medium [35] indicating that this foreign gene is still subjected to some kind of chitosan-dependent regulation in the heterologous host. However, the addition of chitosan as a component in any culture medium is not without problems due to the well known anti-microbial properties of this polysaccharide $[9,10]$ which can slow down the bacterial growth.

Here, we show that the expression of the heterologous gene csnN106 in S. lividans is regulated at the transcriptional level. This led us to engineer a new expression system which does not require anymore the presence of chitosan or its derivatives as inducers of enzyme production.

\section{Results}

\section{The rationale of genetic constructions}

The integrative plasmid pHM8aB $\Delta M[36,37]$, was used in studies involving the regulation of gene $\operatorname{csnN} 106$ expression. The $\operatorname{csnN106}$ gene was present in a single copy in the genome, avoiding the regulatory interference brought by multi-copy plasmids.
By primer extension, we determined the start site for mRNA transcribed from $\operatorname{csnN106}$ (Figure 1 and Figure $2 \mathrm{~A}$ ), defining the probable -35 and -10 boxes of the promoter of $\operatorname{csnN106}$ as TTGCGC and TTCAAT with a spacer of 18 nucleotides (shown in blue on Figure 2A). To test another promoter, described as a "strong" promoter by Labes et al. [38], the original -35 and -10 boxes of $c s n N 106$ gene were substituted with the two tandemly arrayed and overlapping promoters of the Streptomyces ghanaensis phage I19, taking the respective transcription start sites as reference (Figure 2A).

A palindromic sequence overlaps the transcriptional start site of csnN106 (Figure 2A). Highly similar sequences are also present upstream from the coding sequences of chitosanase genes found in other genomes of actinomycetes, displaying a clear consensus (Figure 2B). Previous gel retardation experiments have shown an interaction between a protein present in partially purified cell extract from Kitasatospora sp. N106 and a short DNA segment including the palindromic sequence [39].

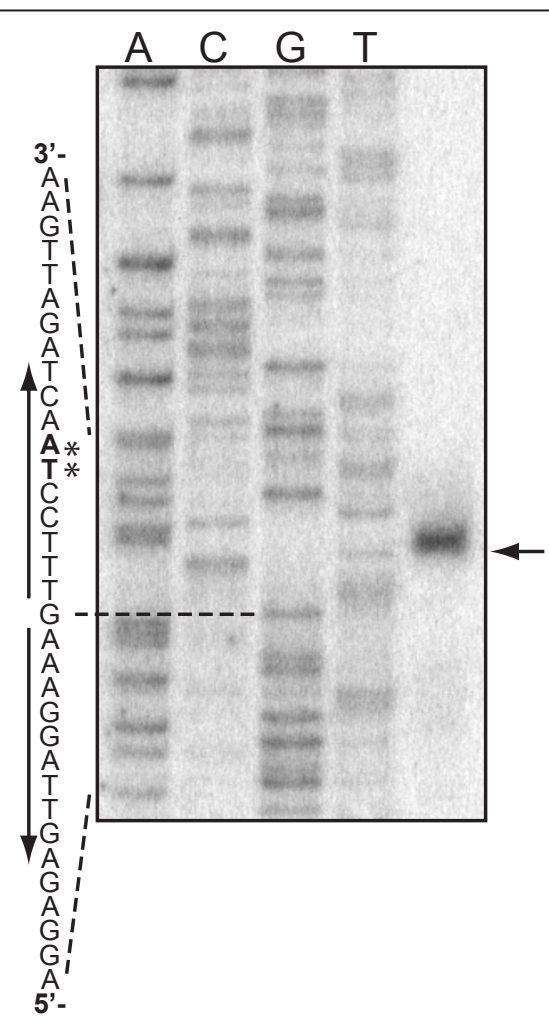

Figure 1 Primer extension analysis of csnN106 transcripts. The apparent $5^{\prime}$ terminus for the csnN106 transcript was identified by annealing a radiolabeled primer complementary to the mRNA of csnN106 and extension with reverse transcriptase. $40 \mu \mathrm{g}$ of total RNA, from GlcN-chitosan oligomers induced S. lividans TK24(pHPrWT), were used for extension reaction. The same primer was used for DNA sequencing reactions with the pHPr-WT plasmid. $(\rightarrow)$ : primer extension product; $\left(^{*}\right)$ : apparent transcription start site. Vertical arrows: palindromic sequence. 


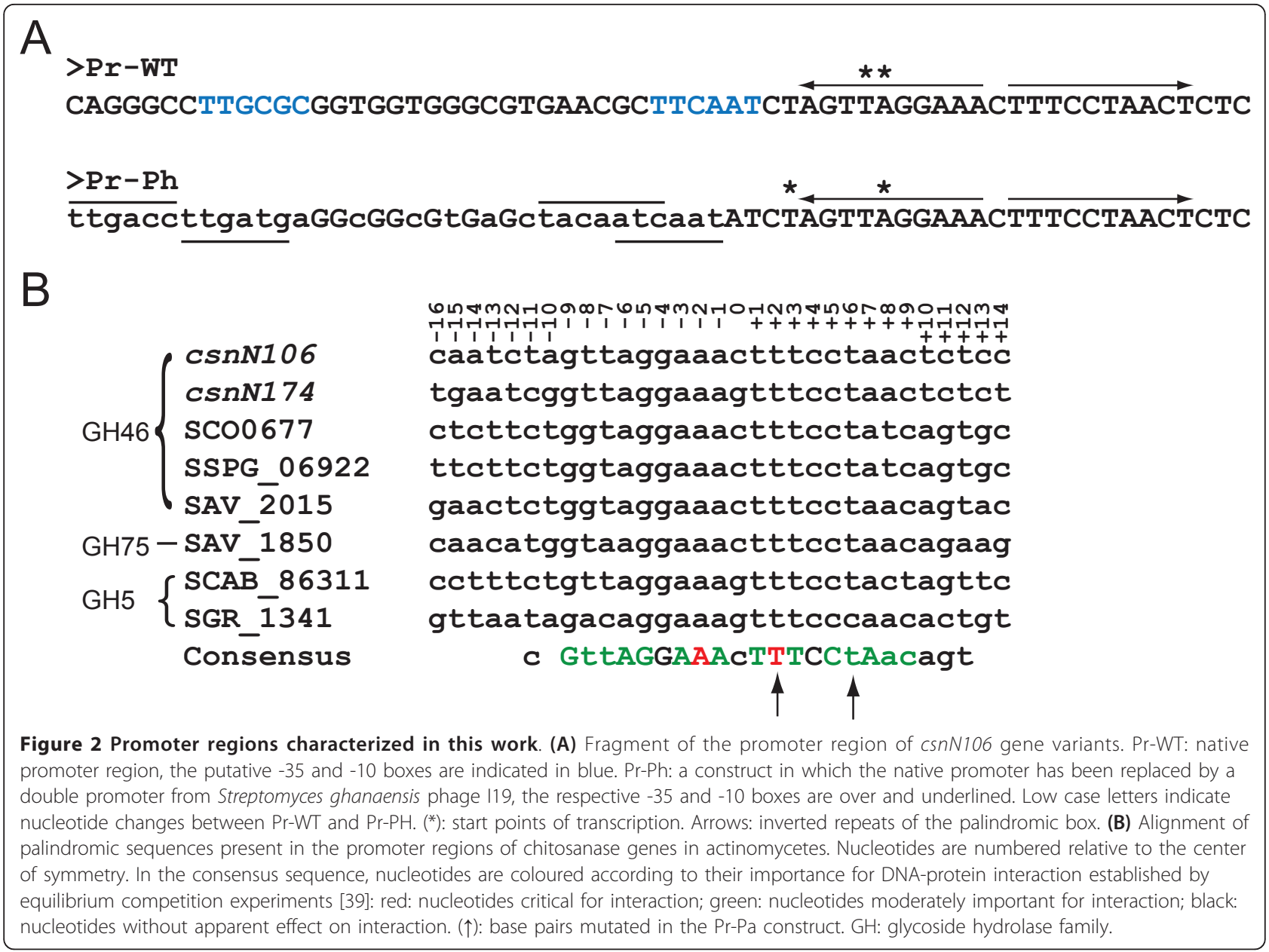

Competition tests with mutated oligonucleotides allowed determining the bases which were critical for the interaction with the regulatory protein in vitro (Figure 2B) [39]. For the present study, two most important base pairs in the right half of the palindromic sequence were mutated (while keeping intact the original -10 and -35 promoter boxes) and introduced upstream from the $\operatorname{csnN106}$ coding sequence, resulting in a third version of this heterologous gene. These three genes were introduced in two hosts: Streptomyces lividans TK24 (the host used so far in most works involving actinobacterial chitosanase studies) and a mutant harbouring an in-frame deletion in $\operatorname{csn} R$ gene $(\Delta \operatorname{csn} R$, formerly described as $\Delta 2657 h$ by Dubeau et al. [37]). The csnR gene (SSPG_04872, according to GenBank annotation) is coding for the transcriptional regulator of the endogenous chitosanase gene (Dubeau, M.-P., Poulin-Laprade, D., Ghinet, M. G., Brzezinski, R.: Characterization of CsnR, the transcriptional repressor of the chitosanase gene of Streptomyces lividans, submitted), a protein belonging to the ROK family created by Titgemeyer et al. [40].
Crude extracts prepared from the cells of both strains cultivated in the presence of chitosan oligosaccharides (a mixture of GlcN and chitosan oligomer) were used in gel retardation experiments using a ${ }^{32} \mathrm{P}$-labelled oligonucleotide including the palindromic sequence from $\operatorname{csnN106}$ as a probe. A shift in mobility was observed with the extract from the wild type strain but not with $\triangle \operatorname{csnR}$ mutant (Figure 3). The CsnR protein from S. lividans binds then efficiently the palindromic sequence of the heterologous $\operatorname{csnN106}$ gene.

Regulation of csnN106 chitosanase gene expression in the heterologous host

To investigate the regulation of the csnN106 gene in $S$. lividans, various versions of the heterologous chitosanase gene have been cloned into derivatives of the integrative vector $\mathrm{pHM} 8 \mathrm{a}$. The wild-type and $\Delta c s n R$ strains of $S$. lividans, harbouring integrated variants of the csnN106 gene were cultivated in minimal media with either mannitol or a mix of chitosan oligosaccharides as carbon source. Samples of culture supernatants were 


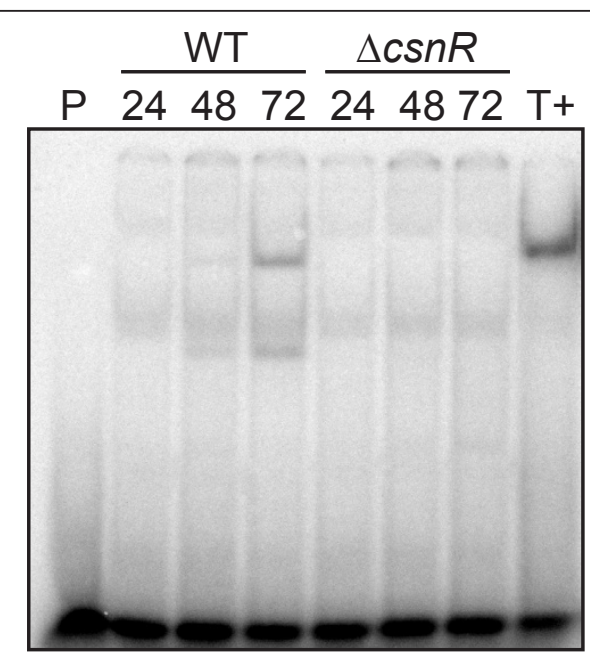

Figure 3 Effect of $c s n R$ deletion on DNA-protein interaction at the csnN106 gene operator. Gel retardation experiment was set up combining $0.1 \mathrm{nM}$ double strand oligonucleotide probe covering the palindromic box of csnN106 with $10 \mu \mathrm{g}$ of crude protein extracts from S. lividans TK24 strain (WT) or the csnR deleted strain $(\Delta c s n R)$ cultivated in medium with $0.125 \% \mathrm{GlcN}$ and $0.375 \%$ chitosan oligomers for the time (hours) indicated. P: probe only; T+: control reaction with $2 \mu \mathrm{g}$ of partially purified protein from Kitasatospora sp. N106 [39].

collected after various incubation times and chitosanase activity and dry mycelia mass were measured. Figure 4 shows the chitosanase activities (expressed as Units/mg of dry mass to normalize with culture growth) attained after $16 \mathrm{~h}$. The induction ratio is calculated dividing the activity obtained in the presence of chitosan oligosaccharides by that obtained in mannitol medium. Combining the host genotype, the chitosanase gene promoter and the palindromic sequence in their wild type forms resulted in the highest induction ratio $(12.8 \mathrm{x})$ indicating the extent of negative regulation of the $\operatorname{csnN} 106$ gene in the heterologous host. When the $\operatorname{csn} R$ gene was deleted or when the operator of $c s n N 106$ gene was mutated, the difference among activities produced in the presence and in the absence of chitosan became not significant or of low significance, resulting in low values of induction ratios $(2.5$ - 3.9), due essentially to derepression of chitosanase production in mannitol medium. The expression of the chitosanase gene with the phage-type promoter followed a similar pattern. Overall however, the phage-type promoter did not direct higher chitosanase production levels and was not included in further studies.

Globally, these results indicate that the palindromic sequence and the $\operatorname{csn} R$ gene function as a negative regulation system of the $\operatorname{csnN106}$ gene in the heterologous S. lividans host. This mode of regulation is very similar to the one exerted on the endogenous chitosanase gene (csnA) of S. lividans TK24 (Dubeau et al., submitted).

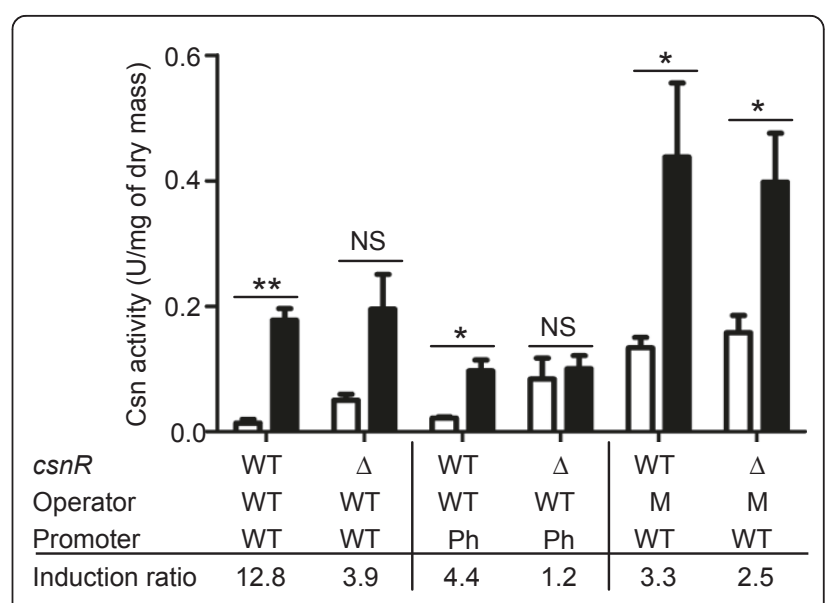

Figure 4 Effect of mutations in csnN106 gene and S. lividans host on chitosanase production. Chitosanase activity was assayed in supernatants sampled from $16 \mathrm{~h}$ cultures. Media: M14 M with $0.5 \%$ mannitol (empty columns) or M14 M with $0.125 \% \mathrm{Gl} c \mathrm{~N}$ and $0.375 \%$ chitosan oligomers (filled columns). Data and error bars are the mean of three experiments. ${ }^{*} P \leq 0.01,{ }^{*} P \leq 0.05$ obtained with an unpaired t test (GraphPad Prism version 5.00 for Windows; GraphPad Software, San Diego, CA). The table lists the genotypes of strains for each pair of columns. Variants of csnN106 gene were introduced in one copy per genome via an integrative vector. Symbols: WT: wild type; $\boldsymbol{\Delta}$ : $\Delta c s n R$ mutant host; $\mathbf{M}$ : mutated palindromic box; Ph: phage-type promoter. The induction ratio represents the chitosanase activity of culture induced with GlcN and chitosan oligomer divided by the activity of culture in mannitol medium.

\section{Chitosanase production in the absence of chitosan or derivatives}

In our previous work, efficient production of chitosanase by either native or recombinant actinobacterial strains was strictly dependent on the addition of chitosan or derivatives (GlcN or chitooligosaccharides) in the culture media. The regulatory derepression, observed in the S. lividans $\triangle c s n R$ host harbouring the chitosanase gene with the mutated operator sequence raised the possibility to produce chitosanase in the absence of such inducers, using only inexpensive media components. Testing various concentrations of malt extract, salt formulations and methods of inoculation allowed obtaining routinely activities in the range of $10-12$ units per $\mathrm{ml}$ and, in the best case, up to 24 units per ml (not shown). Protease activity was also highly dependent on medium composition and type of inoculum. Addition of magnesium ions was found to be essential to promote efficient chitosanase production (and low level of protease), while the microelements of the M14 M medium could be omitted (not shown).

In previous work, chitosanase production was performed with $S$. lividans TK24 harbouring csn genes originating from various bacterial species cloned in multicopy plasmids [35]. To compare the new gene/host 
combination with the former ones, we cloned the $\operatorname{csnN} 106$ gene (with a wild type operator) into the multicopy vector pFDES [28] and introduced it in the wild type host. In parallel, the same plasmid but with the mutated operator has been introduced into the $\Delta \operatorname{csn} R$ host. Chitosanase production by these two strains has been compared with that directed by the csnN106 gene (with the mutated operator) on a derivative of the integrative vector pHM8a in the $\Delta \operatorname{csn} R$ host. Three media formulations were tested: a medium containing malt extract as main nutrient source, a medium with chitosan flakes and GlcN, often used in our previous work, and a medium with more expensive components, GlcN and chitosan oligomers, used in basic research for the induction of chitosanase gene expression (Figure 4). On Figure 5 only the $72 \mathrm{~h}$ time point is presented, as chitosanase level was maximal around this time point and then remained stable or slightly decreased. The culture in medium with chitosan flakes and GlcN gives the best chitosanase level for the strain keeping intact both partners of the regulatory interaction (Figure 5A). However, cultures in media with chitosan gave much higher levels of extracellular proteases (Figure $5 \mathrm{~B}$ ). The $\Delta c s n R$ host harbouring the chitosanase gene on a integrative vector produced equivalent enzyme activities in the malt extract medium and in the chitosan flakes medium (Figure 5A), confirming the possibility to produce chitosanase in the absence of any chitosan derivative, with a much lower level of extracellular proteases (Figure 5B). Furthermore, the analysis of total extracellular proteins by SDS-PAGE revealed that there were less contaminant proteins in the malt extract medium than in the chitosan flakes medium (Figure $5 \mathrm{C}$ ). In $\triangle \operatorname{csn} R$ host there was no particular advantage to use the multicopy plasmid over the integrative vector, the latter being more advantageous as it did not require the addition of any antibiotic to the medium. The $\triangle \operatorname{csn} R$ host seems to be particularly useful for the inexpensive production of almost pure chitosanase in stable, low-protease conditions.

\section{Discussion}

This report is the first study dedicated to the genetic regulation of a heterologous chitosanase gene in S. lividans. We have shown that $\mathrm{CsnR}$ regulates negatively the expression of $\operatorname{csnN106}$ gene. Deletion of $\operatorname{csnR}$ or mutations in the operator sequence of csnN106 resulted in the derepression of expression in the absence of inducer molecules. However, even in the derepressed gene/host combination, some residual induction by chitosan derivatives was still observed. This could be due to a regulator responding directly to the presence of chitosan or indirectly, through a stress pathway resulting from the interaction between chitosan and the cell. A complex transcriptomic response has been observed after contact with chitosan in cells of Staphylococcus aureus [41] and Saccharomyces cerevisiae [42].

One usual way to change the genetic regulation of a given gene is done by promoter replacement. In our earlier work, testing three different promoters from streptomycetes did not led to the improvement of chitosanase production [43]. In this work, we decided to replace only the -35 and -10 boxes from $\operatorname{csnN} 106$ promoter sequence while conserving all the remaining segments. Despite the use of a promoter considered as strong [38], this substitution did not result in better chitosanase production. For reasons that remain unclear, the chitosanase expression was less efficient for a total of four different hybrid gene constructions when the protein coding sequence of Csn was separated from its native upstream segment. This could result from a lower stability of mRNAs transcribed from these hybrid genes, but this remains to be investigated.

Masson et al. [35] optimized a chitosanase production medium for the CsnN174 production in the heterologous host S. lividans. They showed that the addition of malt extract to the chitosan medium was beneficial for enzyme production. We then based our media formulations on malt extract in our attempts to produce chitosanase with the new gene/host combination in the absence of chitosan. We have shown that equivalent, and sometimes higher chitosanase levels can be obtained without the addition of chitosan to the culture medium. Interestingly, the new medium/host combination resulted in much lower levels of contaminant proteins in the supernatant. Finally, in earlier culture media formulations including chitosan flakes, a raise of extracellular protease activity at later culture stage could often result in a rapid loss of chitosanase activity [35]. The new medium/host combination provides a substantial improvement, as protease levels are much lower, resulting in stable chitosanase production.

\section{Conclusions}

The chitosanase production system based on a new medium/host combination was shown to be at least as efficient as the former one without the necessity to include chitosan or derivatives into the culture medium. Extensive optimization of culture parameters will probably lead to much higher chitosanase activities. For biotechnology, the new host will be of interest for large scale chitosanase production as only inexpensive media components can be used. For basic research, it will be particularly useful for the introduction of carbon or nitrogen isotopes into the chitosanase molecule, originating from defined sources such as ${ }^{13} \mathrm{C}$-glucose or ${ }^{15} \mathrm{NH}_{4} \mathrm{Cl}$ and for the production of highly pure chitosanase proteins for crystallography. This will contribute to a further advance in structure-function studies of chitosanases. 


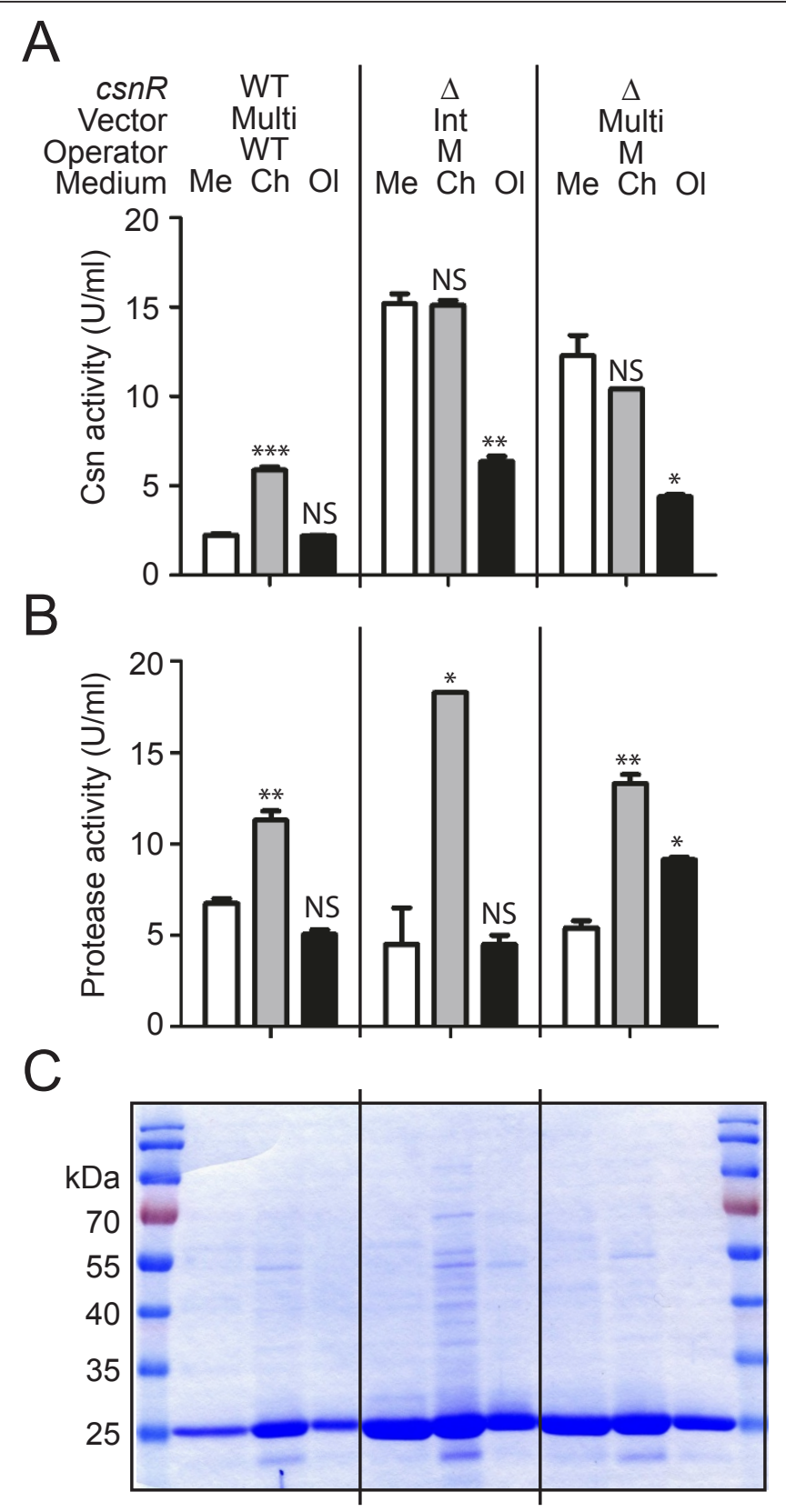

Figure 5 Chitosanase activity and relative purity assessment and assay of protease levels. (A) chitosanase activity; (B) protease activity; (C) SDS-PAGE of proteins in culture supernatants. The upper-table aligns the genotype of each strain and lists the type of medium for the corresponding columns in graphs (A) and (B) and wells of (C). Genetic symbols as in Fig. 4. Multi: chitosanase genes introduced on a multicopy vector; Int: chitosanase genes introduced on an integrative vector. Culture media: Me: malt extract medium; Ch: chitosan flakes medium; Ol: medium with GlcN and chitosan oligomers. All determinations have been done after $72 \mathrm{~h}$ of culture. Data and error bars (A and B) are the mean of culture duplicates. ${ }^{* *} \mathrm{P} \leq 0.001,{ }^{* *} \mathrm{P} \leq 0.01,{ }^{*} \mathrm{P} \leq 0.05$ from one-way ANOVA with Bonferroni's post test (GraphPad Prism version 5.00). (C) $20 \mu \mathrm{l}$ of culture supernatants were loaded on a 12\% SDS-PAGE gel. PageRulerTMprestained protein ladder (0.5 $\mu$ l; Fermentas) was used as standard. After electrophoresis, proteins were stained with Coomassie brilliant blue. Chitosanase migrates as a 26.5 kDa band.

\section{Methods}

\section{Bacterial strains and general culture conditions}

E. coli strain DH5 $\alpha^{\mathrm{TM}}$ (Invitrogen) was used for cloning experiments and DNA propagation. E. coli $\mathrm{DH} 5 \alpha^{\mathrm{TM}_{\mathrm{W}}}$ grown on Luria-Bertani broth supplemented with $500 \mu \mathrm{g} /$ $\mathrm{ml}$ hygromycin $(\mathrm{Hm})$ or $50 \mu \mathrm{g} / \mathrm{ml}$ kanamycin $(\mathrm{Km})$. Standard methods were used for E. coli transformation, plasmid isolation and DNA manipulation [44]. Streptomyces lividans TK24 [45] and S. lividans $\Delta c s n R$ [37] were used as hosts for chitosanase genes. Preparation of S. lividans 
protoplasts and transformation using rapid small-scale procedure and $\mathrm{R} 5$ regeneration medium were performed as described previously [45]. After DNA transfer, hygromycin or kanamycin-resistant colonies were selected after addition of $5 \mathrm{mg} \mathrm{Hm}$ or $\mathrm{Km}$ to $2.5 \mathrm{ml}$ of soft agar overlay. Transformants were chosen following two subsequent cycles of purification on solid yeast/malt extract (YME) medium [45] with $250 \mu \mathrm{g} / \mathrm{ml} \mathrm{Hm}$ or $\mathrm{Km}$. Sporulation was obtained by heavy inoculation of SLM3 agar medium plates [46]. Spores were collected with glass beads and stored in $20 \%$ glycerol at $-20^{\circ} \mathrm{C}$.

\section{Gel mobility shift assay}

$10^{8}$ spores of $S$. lividans TK24 or S. lividans $\Delta c s n R$ were inoculated into $50 \mathrm{ml}$ of Tryptic soy broth (TSB, Difco) and grown for $64 \mathrm{~h}$ at $30^{\circ} \mathrm{C}$ with shaking. Cultures were centrifuged, the mycelial pellets were washed with sterile $0.9 \%$ saline and suspended in two volumes of saline. Then, $1 \mathrm{mpv}$ (equivalent of $1 \underline{\mathrm{ml}}$ of pellet volume) was added to $100 \mathrm{ml}$ of induction medium. Induction medium is a modified M14 medium (M14M) [47] composed of $0.1 \% \mathrm{KH}_{2} \mathrm{PO}_{4}, 0.55 \% \mathrm{~K}_{2} \mathrm{HPO}_{4}, 0.14 \%\left(\mathrm{NH}_{4}\right)_{2} \mathrm{SO}_{4}, 0.1 \%$ of trace elements solution ( $2 \mathrm{~g} / \mathrm{L} \mathrm{CoCl}_{2} \cdot 7 \mathrm{H}_{2} \mathrm{O}, 5 \mathrm{~g} / \mathrm{L} \mathrm{FeS}$ $\left.\mathrm{O}_{4} \cdot 7 \mathrm{H}_{2} \mathrm{O}, 1.6 \mathrm{~g} / \mathrm{L} \mathrm{MnSO}_{4} \cdot \mathrm{H}_{2} \mathrm{O}, 1.4 \mathrm{~g} / \mathrm{L} \mathrm{ZnSO}_{4} \cdot 7 \mathrm{H}_{2} \mathrm{O}\right)$, $\mathrm{pH}$ 6.9. Before use, $0.03 \% \mathrm{MgSO}_{4}, 0.03 \% \mathrm{CaCl}_{2}, 0.125 \%$ GlcN and $0.375 \%$ chitosan oligomers (1:1 dimer-trimer mix) was added to the M14 M. Cultures were incubated at $30^{\circ} \mathrm{C}$ with shaking. Every $24 \mathrm{~h}, 10 \mathrm{ml}$ of culture were collected and centrifuged and pellets were kept frozen at $-80^{\circ} \mathrm{C}$. Pellets were melted on ice, washed with cold extraction buffer (50 mM Tris, $60 \mathrm{mM} \mathrm{NaCl}, 5 \%$ glycerol, $1 \mathrm{mM}$ EDTA, 1 mM DL-dithiothreitol (DTT), pH 8.0) and suspended in $1 \mathrm{ml}$ of extraction buffer containing a protease inhibitor cocktail (Complete ${ }^{\mathrm{TM}}$; Roche Molecular Biochemicals). The bacterial cells were then disrupted by sonication with one treatment of $40 \mathrm{~s}$ at $40 \%$ amplitude (Vibra-Cell ${ }^{\mathrm{TM}}, 130 \mathrm{Watt} 20 \mathrm{kHz}$, Sonics and materials inc., USA). Total protein extracts were centrifuged at $3000 \mathrm{~g}$ for $10 \mathrm{~min}$ at $4^{\circ} \mathrm{C}$. Supernatants were then frozen and stored at $-80^{\circ} \mathrm{C}$ until used.

The double-stranded $\operatorname{csnN106}$ palindromic probe (MP12F) was prepared by complementary oligonucleotide annealing and end-labeling with $\left[\gamma-{ }^{32} \mathrm{P}\right]$ ATP (PerkinElmer) and $\mathrm{T} 4$ polynucleotide kinase as described by Dubeau et al. [36]. DNA binding reactions $(24 \mu \mathrm{l})$ contained $10 \mathrm{mM}$ HEPES (pH 7.9), 10\% glycerol, $0.2 \mathrm{mM}$ EDTA, 0.5 mM PMSF, $0.25 \mathrm{mM}$ DTT, $1 \mu \mathrm{g}$ poly $(\mathrm{dI}-\mathrm{dC})$, $150 \mathrm{mM} \mathrm{KCl}, 0.1 \mathrm{nM}$ of labeled probe and $10 \mu \mathrm{g}$ of protein crude extract. The reaction mixtures were incubated at room temperature for $15 \mathrm{~min}$ and then subjected to electrophoresis in a pre-run gel of $6 \%$ polyacrylamide $(10 \mathrm{mM}$ Tris, $80 \mathrm{mM}$ glycine, $0.4 \mathrm{mM}$ EDTA, pH 8.3). The gel was dried and viewed with a Phosphorimager (Molecular Dynamics).

\section{Vector construction}

The $c s n N 106$ gene fragment (GenBank accession number L40408.1) was amplified by PCR reaction using FwcsnN106 and RvcsnN106 primers (Table 1) and plasmid pCSN106-2 as template [32]. The amplified SphI HindIII fragment was cloned into the integrative vector pHM8aB $\triangle \mathrm{M}$ [37] or pFDES [28] digested with the same enzymes, giving respectively plasmids $\mathrm{pHM} 8 \mathrm{aB} \Delta \mathrm{M}$ $\operatorname{csnN106}$ and pFDES-csnN106. The promoter region of csnN106 (Pr-WT) was PCR-amplified with primers FwPr-WT and RvPr-WT. Purified PCR fragment was cloned between $B a m \mathrm{HI}$ and SphI restriction sites of pHM8aBAM-csnN106 and pFDES-csnN106 generating pHPr-WT and pFPr-WT. A mutated version of Pr-WT with two base-pairs substitutions in the palindromic

Table 1 Oligonucleotides used in this study

\begin{tabular}{lll}
\hline Aim of primers & Name & Sequence $\left(\mathbf{5}^{\prime} \rightarrow \mathbf{3}^{\prime}\right)$ \\
\hline For csnN106 coding region cloning* & FwcsnN106 & CCGGAGACCCGCATGCCCCGGAC \\
\hline For Pr-WT cloning* & RvcsnN106 & CGGGCGCCAAGCTTGCGTTCGG \\
\hline PCR-directed mutagenesis for Pr-Pa cloning ${ }^{* *}$ & FwPr-WT & GTCTGCGCGATCCTGACGGCCC \\
& RvPr-WT & GTCGGGGCATGCGGGTCTCCGG \\
\hline Verification of pHM8a derivatives integration into hosts & SEQ.1 & ACAACTTCGTCGCGCACATCCA \\
& Rw1Pr-Pa & ATGAGGAGAGTCGGACAGTTC \\
\hline Presence verification of pFDES derivatives into hosts & Fw2Pr-Pa & GAAACTGTCCGACTCTCCTCAT \\
& RvcsnN106 & TGAGGTCGAAGTCTTGGCGTT \\
\hline For Primer extension & Fwgenom & CCTGAGAGGCCGGTGAGGAG \\
\hline
\end{tabular}

*Bold nucleotides correspond to restriction site.

**Bold nucleotide correspond to mutated nucleotide. 
operator (Pr-Pa) was obtained with the PCR-directed mutagenesis method [48] using SEQ.1, Rv1Pr-Pa, Fw2Pr-Pa and RvcsnN106 as primers (Table 1) and the pFPr-WT plasmid as DNA template. The mutated PCR product was digested with $B a m \mathrm{HI}$ and $S p h \mathrm{I}$ and cloned into pHM8aB $\Delta \mathrm{M}-\operatorname{csnN} 106$ and pFDES-csnN106 generating $\mathrm{pHPr}-\mathrm{Pa}$ and $\mathrm{pFPr}-\mathrm{Pa}$. The phage-type version of csnN106 promoter (Pr-Ph) was obtained by annealing two short DNA segments:

5'-GATCCTGACGGCCCGTCCGCCCAGCGGTACG AGGGCCCCGACCGGAGTTCCGGTCGGGGCCTTTC GCATGACCGCGCGGGCAAACATGGCGCTTGACC TTGATGAGGCGGCGTGAGCTACAATCAATATC TAGTTAGGAAACTTTCCTAACTC TCCTCATGGGT CCGGAGACCCGCATG-3' and 5'-CGGGTCTCCGGAC CCATGAGGAGAGTTAGGAAAGTTTCCTAACTAG ATATTGATTGTAGCTCACGCCGCCTCATCAAGG TCAAGCGCCATGTTTGCCCGCGCGGTCATGCGA AAGGCCCCGACCGGAACTCCGGTCGGGGCCCTCG TACCGCTGGGCGGACGGGCCGTCAG-3'.

As a result, the double-stranded oligonucleotide with "ready-to-clone" cohesive-ends was ligated with pHM8aBAM-csnN106 digested with BamHI and SphI generating $\mathrm{pHPr}-\mathrm{Ph}$. All constructions were verified by DNA sequencing (Genome Quebec Innovation Center, McGill University, Canada).

Plasmids were introduced into S. lividans strains by transformation and selection with $\mathrm{Hm}$ for pHM8a derivatives carrying hyg or selection with $\mathrm{Km}$ for pFDES derivatives carrying neoS as resistance gene. Integration of pHM8a derivatives into the genome of their hosts and the presence of pFDES derivatives were verified by PCR using primers in Table 1.

\section{Transcription startpoint mapping by primer extension}

$10^{8}$ spores of $S$. lividans TK24(pHPr-WT) strain were inoculated into $50 \mathrm{ml}$ of TSB with $50 \mu \mathrm{g} / \mathrm{ml} \mathrm{Hm}$ and grown for $64 \mathrm{~h}$ at $30^{\circ} \mathrm{C}$ with shaking. Chitosanase gene expression was obtained in M14 M medium with GlcN and chitosan oligomers as described for gel mobility shift assay. After $14 \mathrm{~h}$, four culture samples of $10 \mathrm{ml}$ each were collected and mixed immediately with stop solution ( 0.2 volumes of ethanol-equilibrated phenol, 95:5). Samples were centrifuged for $10 \mathrm{~min}$ at $4^{\circ} \mathrm{C}$. Bacterial pellets were frozen at $-80^{\circ} \mathrm{C}$ until lysis. Total RNA extraction was carried out using the Qiagen RNeasy ${ }^{\circledR}$ Mini Kit (Qiagen) with the following modifications. Cell disruption was achieved by sonication with two $30 \mathrm{~s}$ burst at $35 \%$ amplitude separated with a $15 \mathrm{~s}$ cooling period, followed by two phenol-chloroform extractions and one chloroform extraction for cell debris elimination. The on-column DNase treatment was done with the RNase-free DNase set (Qiagen). RNA purity and concentration were assessed in a NanoDrop ${ }^{\mathrm{TM}} 1000$ spectrophotometer (Thermo Scientific). RNA quality was verified by electrophoresis on agarose gel in $1 \times$ MOPS electrophoresis buffer with $0.22 \mathrm{M}$ formaldehyde [44].

20 pmoles of PE-csnN106 primer (Table 1) were endlabeled with $\left[\gamma-{ }^{32} \mathrm{P}\right]$ ATP (PerkinElmer) and 20 units of T4 polynucleotide kinase, then purified on a G-25 column (GE Healthcare). Total RNA $(40 \mu \mathrm{g})$ was hybridized with the end-labeled primer $(0.5$ pmole $)$ in the presence of $10 \mathrm{mM}$ Tris- $\mathrm{HCl} \mathrm{pH} 8.6,300 \mathrm{mM} \mathrm{NaCl}$ and $1 \mathrm{mM}$ EDTA, in a volume of $22 \mu \mathrm{l}$ by incubation at $95^{\circ} \mathrm{C}$ for $5 \mathrm{~min}$, then $55^{\circ} \mathrm{C}$ for $90 \mathrm{~min}$. ARN/primer mix was then precipitated with $200 \mu \mathrm{l}$ ammonium acetate 1 $\mathrm{M}$ and $200 \mu \mathrm{l}$ isopropanol. The pellet was washed with $70 \% \mathrm{EtOH}$, dried and suspended in $10 \mu \mathrm{l}$ of $10 \mathrm{mM}$ Tris- $\mathrm{HCl}(\mathrm{pH} 8.6)$, reverse transcriptase buffer $(1 \times$, Promega), $10 \mathrm{mM}$ DTT, $1 \mathrm{mM}$ dNTPs, $1 \mu \mathrm{g}$ actinomycine D, 5 units of AMV reverse transcriptase (Promega) and 20 units of RNAsin (Promega) for a total volume of 20 $\mu$ l. The reaction mixture was incubated at $45^{\circ} \mathrm{C}$ for 60 min and stopped with formamide dye. A sequencing reaction was performed with the end-labeled primer, the pHPr-WT plasmid as DNA template and the ALFexpress ${ }^{\mathrm{TM}}$ AutoCycle ${ }^{\mathrm{TM}}$ Sequencing Kit (Amersham Biosciences) using manufacturer's recommendations. The primer extension sample and the sequence reactions were heated $5 \mathrm{~min}$ at $95^{\circ} \mathrm{C}$ just before loading on a $6 \%$ polyacrylamide sequencing gel. The gel was run, dried, visualised and analyzed by a Phosphorimager and the ImageQuant Version 5.2 software (Molecular Dynamics).

\section{Chitosanase production experiments}

A first procedure was used for experiments presented on Figure 4. $10^{8}$ spores of S. lividans strains (transformed with plasmids pHPr-WT, pHPr-Pa or $\mathrm{pHPr}-\mathrm{Ph}$ ) were inoculated into $50 \mathrm{ml}$ of TSB with $50 \mu \mathrm{g} / \mathrm{ml} \mathrm{Hm}$ and grown for $48 \mathrm{~h}$ at $30^{\circ} \mathrm{C}$ with shaking. After centrifugation, bacterial pellets were transferred into M14 M with $0.125 \%$ GlcN and $0.375 \%$ chitosan oligomers (induction medium) or 0.5\% mannitol (control medium), as described for gel mobility shift experiments. Samples of cultures of $10 \mathrm{ml}$ each were collected at $12 \mathrm{~h}, 16 \mathrm{~h}$, $22 \mathrm{~h}$ and $38 \mathrm{~h}$ and centrifuged. Chitosanase activity was determined in the culture supernatants, while pellets were used for dry weight measurement determination, drying overnight at $50^{\circ} \mathrm{C}$.

A second procedure was used for the experiments presented on Figure 5. $10^{9}$ spores of S. lividans strains (WT + pFPr-WT, $\Delta c s n R+$ pHPr-Pa, $\Delta c s n R+$ pFPr-Pa) were inoculated into $50 \mathrm{ml}$ of TSB supplemented with $50 \mu \mathrm{g} / \mathrm{ml} \mathrm{Km}(\mathrm{WT}+\mathrm{pFPr}-\mathrm{WT}$ and $\Delta \operatorname{csn} R+\mathrm{pFPr}-\mathrm{Pa})$ or $50 \mu \mathrm{g} / \mathrm{ml} \mathrm{Hm}(\Delta \operatorname{csn} R+\mathrm{pHPr}-\mathrm{Pa})$ and grown for $64 \mathrm{~h}$ at $30^{\circ} \mathrm{C}$ with shaking. Three types of culture were tested. First, a rich, malt extract-based medium $(4 \times$ M14 M 
without microelements, $0.12 \% \mathrm{MgSO}_{4}, 2 \%$ malt extract) was directly inoculated with a portion of the pre-culture in TSB corresponding to an inoculation proportion of 4 $\mathrm{mpv} / 100 \mathrm{ml}$. Second, $100 \mathrm{ml}$ of chitosan medium (M14 M, $0.03 \% \mathrm{MgSO}_{4}, 0.03 \% \mathrm{CaCl}_{2}, 0.2 \%$ malt extract, $0.8 \%$ chitosan flakes (Sigma), 0.2\% GlcN) was inoculated with $1 \mathrm{mpv}$ of saline washed pre-culture. Third, $100 \mathrm{ml}$ of GlcN/chitosan oligomer medium (M14 M, 0.03\% $\mathrm{MgSO}_{4}, 0.03 \% \mathrm{CaCl}_{2}, 0.125 \%$ GlcN and $0.375 \%$ chitosan oligomers) was inoculated with $1 \mathrm{mpv}$ of saline washed pre-culture. For each WT + pFPr-WT and $\Delta c s n R+$ pFPr-Pa flasks, $50 \mu \mathrm{g} / \mathrm{ml} \mathrm{Km}$ was added. Cultures were done in duplicate and incubated at $30^{\circ} \mathrm{C}$ with shaking. $10 \mathrm{ml}$ samples were collected every $24 \mathrm{~h}$. Chitosanase and protease activities and total protein concentration were determined in supernatants.

\section{Biochemical procedures}

Chitosanase activity was measured using the dyed substrate sRBB-C [49]. Briefly, $50 \mu \mathrm{l}$ of appropriately diluted culture supernatant were added to $950 \mu \mathrm{l}$ of soluble Remazol Brilliant Blue chitosan $(5 \mathrm{mg} / \mathrm{ml}$ in $0.1 \mathrm{M} \mathrm{Na}$ acetate buffer $\mathrm{pH} 4.5$ ) and the mixture was incubated for $60 \mathrm{~min}$ at $37^{\circ} \mathrm{C}$. Reaction was stopped with $500 \mu \mathrm{l}$ of $1.2 \mathrm{~N} \mathrm{NaOH}$ and cooled on ice for $20 \mathrm{~min}$. After centrifugation, the optical density of supernatant was read at $595 \mathrm{~nm}$ and converted into chitosanase activity as described [49].

Protein concentration was estimated by the method of Bradford [50], with bovine serum albumin as standard. Protease activity was determined with azocasein [51].

\section{Acknowledgements}

The authors thank Édith Sanssouci for providing the pFDES vector and Dr. Tamo Fukamizo for helpful discussions. This work was supported by a Discovery grant from Natural Science and Engineering Research Council (NSERC) of Canada to RB. M-PD is the recipient of doctoral student fellowships from NSERC and Fonds québécois de recherche sur la nature et les technologies

\section{Authors' contributions}

$\mathrm{RB}$ and $\mathrm{M}-\mathrm{PD}$ initiated and coordinated the project. RB performed the bioinformatic studies. M-PD performed the plasmids and strains constructions and the DNA retardation experiments. IG and M-PD performed the induction experiments. M-PD and RB wrote the article and all authors approved the final version of the manuscript.

\section{Competing interests}

The authors declare that they have no competing interests.

Received: 23 November 2010 Accepted: 10 February 2011 Published: 10 February 2011

\section{References}

1. Bartnicki-Garcia S: Cell wall chemistry, morphogenesis, and taxonomy of fungi. Ann Rev Microbiol 1968, 22:87-108.

2. Shimahara K, Tagikushi Y, Kobayashi T, Uda K, Sannan T: Screening of Mucoraceae strains suitable for chitosan production. In Chitin and chitosan. Edited by: Skjåk-Bræk G, Anthonsen T, Sandford P. London, New York: Elsevier Applied Science; 1989:171-178.
3. Kapaun E, Reisser W: A chitin-like glycan in the cell wall of a Chlorella sp. (Chlorococcales, Chlorophyceae). Planta 1995, 197:577-582.

4. Roberts GAF: Chitin chemistry. London: MacMillan Press; 1992.

5. Sandford PA: Chitosan: commercial uses and potential applications. In Chitin and chitosan. Edited by: Skjåk-BræK G, Anthonsen T, Sandford P. London, New York: Elsevier Applied Science; 1989:51-69.

6. Furda I: Reduction of adsorption of dietary lipids and cholesterol by chitosan, its derivatives and special formulations. In Advances in Chitin Sciences. Volume IV. Edited by: Peters MG, Domard A, Muzzarelli RAA. Potsdam: Universitat Potsdam; 2000:217-228

7. Blanchard J, Park JK, Boucher I, Brzezinski R: Industrial applications of chitosanases. In Recent Advances in Marine Biotechnology. Volume 9. Edited by: Fingerman M, Nagabhushanam R. New Hampshire: Biomaterials and bioprocessing, Science Publishers; 2003:257-277.

8. Reginster J-Y, Bruyere O, Lecart M-P, Henrotin Y: Naturocetic (glucosamine and chondroitin sulfate) compounds as structure-modifying drugs in the treatment of osteoarthritis. Curr Opin Rheumatol 2003, 15:651-655.

9. Yin H, Du Y, Zhang J: Low molecular weight and oligomeric chitosans and their bioactivities. Curr Top Med Chem 2009, 9:1546-1559.

10. Aam BB, Heggset EB, Norberg AL, Sørlie M, Vårum KM, Eijsink VGH: Production of chitooligosaccharides and their potential application in medicine. Mar Drugs 2010, 8:1482-1517.

11. Hirano S, Kondo Y, Fujii K: Preparation of acetylated derivatives of modified chito-oligosaccharides by the depolymerisation of partially $\mathrm{N}$ acetylated chitosan with nitrous acid. Carbohyd Res 1985, 2:338-341.

12. Vårum KM, Ottoy MH, Smidsrød O: Acid hydrolysis of chitosans. Carbohyd Polym 2001, 46:89-98.

13. Popa-Nita S, Lucas J-M, Ladavière C, David L, Domard A: Mechanisms involved during the ultrasonically induced depolymerisation of chitosan: characterization and control. Biomacromolecules 2009, 10:1203-1211.

14. Eijsink VGH, Vaaje-Kolstad G, Vårum KM, Horn SJ: Towards new enzymes for biofuels: lessons from chitinase research. Trends Biotechnol 2008, 26:228-235.

15. Kuroiwa T, Izuta H, Nabetani H, Nakajima M, Sato S, Mukataka S, Ichikawa S: Selective and stable production of physiologically active chitosan oligosaccharides using an enzymatic membrane bioreactor. Process Biochem 2009, 44:283-287.

16. Dennhart N, Fukamizo T, Brzezinski R, Lacombe-Harvey M-Ë, Letzel T: Oligosaccharide hydrolysis by chitosanase enzymes monitored by realtime electrospray ionization-mass spectrometry. J Biotechnol 2008, 134:253-260.

17. Bueno A, Vazquez de Aldana CR, Correa J, Villa TG, del Rey F: Synthesis and secretion of a Bacillus circulans WL-12 1,3-1,4- $\beta$-D-glucanase in Escherichia coli. J Bacteriol 1990, 172:2160-2167.

18. Ando A, Noguchi K, Yanagi M, Shinoyama H, Kagawa Y, Hirata H, Yabuki M, Fujii T: Primary structure of chitosanase produced by Bacillus circulans MH-K1. J Gen Appl Microbiol 1992, 38:135-144.

19. Shimosaka M, Kumehara M, Zhang XY, Nogawa M, Okazaki M: Cloning and characterization of a chitosanase gene from the plant pathogenic fungus Fusarium solani. J Ferment Bioeng 1996, 82:426-431.

20. Park J K, Shimono K, Ochiai N, Shigeru K, Kurita M, Ohta Y, Tanaka K, Matsuda H, Kawamukai M: Purification, characterization, and gene analysis of a chitosanase (ChoA) from Matsuebacter chitosanotabidus 3001. J Bacteriol 1999, 181:6642-6649.

21. Tanabe T, Morinaga K, Fukamizo T, Mitsutomi M: Novel chitosanase from Streptomyces griseus HUT 6037 with transglycosylation activity. Biosci Biotechnol Biochem 2003, 67:354-364.

22. Gupta V, Prasanna R, Natarajan C, Kumar Srivastava A, Sharma J: Identification, characterization and regulation of a novel antifungal chitosanase gene (cho) in Anabaena spp. Appl Environ Microbiol 2010, 76:2769-2777.

23. Ike M, Ko Y, Yokoyama K, Sumitani J-I, Kawaguchi T, Ogasawara W, Okada H, Morikawa Y: Cellobiohydrolase I (Cel7A) from Trichoderma reesei has chitosanase activity. J Mol Catal B-Enzym 2007, 47:159-163.

24. Johnsen MG, Hansen OC, Stougaard P: Isolation, characterization and heterologous expression of a novel chitosanase from Janthinobacterium sp. strain 4239. Microb Cell Fact 2010, 9:5.

25. Yao Y-Y, Shrestha KL, Wu Y-J, Tasi H-J, Chen C-C, Yang J-M, Ando A, Cheng C-Y, Li Y-K: Structural simulation and protein engineering to convert an endo-chitosanase to an exo-chitosanase. Protein Eng Des Sel 2008, 21:561-566. 
26. Nanjo F, Katsumi R, Sakai K: Purification and characterization of an exo- $\beta$ D-glucosaminidase, a novel type of enzyme, from Nocardia orientalis. J Biol Chem 1990, 265:10088-10094.

27. Nogawa M, Takahashi H, Kashiwagi A, Ohshia K, Okada H, Morikawa Y: Purification and characterization of exo- $\beta$-D-glucosaminidase from cellulolytic fungus, Trichoderma reesei PC-3-7. Appl Environ Microbiol 1998, 64:890-895.

28. Lacombe-Harvey M-Ë, Fukamizo T, Gagnon J, Ghinet MG, Dennhart N, Letzel T, Brzezinski R: Accessory active site residues of Streptomyces sp. N174 chitosanase - variations on a common theme in the lysozyme superfamily. FEBS J 2009, 276:857-869.

29. Denis F, Brzezinski $R$ : A versatile shuttle cosmid vector for use in Escherichia coli and actinomycetes. Gene 1992, 111:115-118.

30. Zhang X-Y, Dai A-L, Zhang X-K, Kuroiwa K, Kodaira R, Shimosaka M, Okazaki M: Purification and characterization of chitosanase and exo- $\beta$-Dglucosaminidase from a koji mold, Aspergillus oryzae IAM2660. Biosci Biotechnol Biochem 2000, 64:1896-1902.

31. Kimoto H, Kusaoke H, Yamamoto I, Fujii Y, Onodera T, Taketo A Biochemical and genetic properties of Paenibacillus glycosyl hydrolase having chitosanase activity and discoidin domain. J Biol Chem 2002, 277:14695-14702.

32. Masson J-Y, Boucher I, Neugebauer WA, Ramotar D, Brzezinski R: A new chitosanase gene from a Nocardioides $\mathrm{sp}$. is a third member of glycosyl hydrolase family 46. Microbiology 1995, 141:2629-2635.

33. Boucher I, Dupuy A, Vidal P, Neugebauer WA, Brzezinski R: Purification and characterization of a chitosanase from Streptomyces N174. Appl Microbiol Biotechnol 1992, 38:188-193.

34. Fink D, Boucher I, Denis F, Brzezinski R: Cloning and expression in Streptomyces lividans of a chitosanase-encoding gene from the actinomycete Kitasatosporia N174 isolated from soil. Biotechnol Lett 1991, 13:845-850.

35. Masson J-Y, Li T, Boucher I, Beaulieu C, Brzezinski R: Factors governing an efficient chitosanase production by recombinant Streptomyces lividans strains carrying the cloned chs gene from Streptomyces N174. In Chitin enzymology. Edited by: Muzzarelli RAA. Lyon: European Chitin Society; 1993:423-430

36. Motamedi H, Shafiee A, Cai S-J: Integrative vectors for heterologous gene expression in Streptomyces sp. Gene 1995, 160:25-31.

37. Dubeau M-P, Ghinet MG, Jacques P-E, Clermont N, Beaulieu C, Brzezinski R: Cytosine deaminase as negative selection marker for gene disruption and replacement in the genus Streptomyces and other actinobacteria. Appl Environ Microbiol 2009, 75:1211-1214.

38. Labes $\mathrm{G}$, Bibb M, Wohlleben $\mathrm{W}$ : Isolation and characterization of a strong promoter element from the Streptomyces ghanaensis phage 119 using the gentamicin resistance gene (aacC1) of Tn1696 as reporter. Microbiology 1997, 143:1503-1512.

39. Dubeau M-P, Broussau S, Gervais A, Masson J-Y, Brzezinski R: A palindromic DNA sequence involved in the regulation of chitosanase gene expression in actinomycetes. In Advances in Chitin Sciences. Volume 8 Edited by: Struszczyk H, Domard A, Peter MG, Pospieszny H. Poznań: Institute of plant protection; 2005:93-100.

40. Titgemeyer F, Reizer J, Reizer A, Saier MH Jr: Evolutionary relationships between sugar kinases and transcriptional repressors in bacteria. Microbiology 1994, 140:2349-2354

41. Raafat D, von Bargen K, Haas A, Sahl H-G: Insights into the mode of action of chitosan as an antibacterial compound. Appl Environ Microbiol 2008, 74:3764-3773

42. Zakrzewska A, Boorsma A, Delneri D, Brul S, Oliver SG, Klis FM: Cellular processes and pathways that protect Saccharomyces cerevisiae cells against the plasma membrane-perturbing compound chitosan. Eukaryot Cell 2007, 6:600-608.

43. Masson J-Y, Boucher I, Guérin SL, Brzezinski R: Effect of regulatory sequence substitution on chitosanase productionfrom a cloned gene in Streptomyces lividans. In Chitin World. Edited by: Karnicki ZS, Bykowski PJ, Wojtasz-Pająk A, Brzeski MM. Wirtschaftsverlag NW, Germany; 1994:311-319.

44. Sambrook J, Russell DW: Molecular cloning: a laboratory manual. 3 edition. Cold Spring Harbor Laboratory Press; 2001

45. Kieser T, Bibb MJ, Buttner MJ, Chater KF, Hopwood DA: Practical Streptomyces genetics The John Innes Foundation, Norwich UK; 2000.

46. DeWitt JP: Evidence for a sex factor in Streptomyces erythraeus. J Bacteriol 1985, 164:969-971.
47. Pagé N, Kluepfel D, Shareck F, Morosoli R: Effect of signal peptide alteration and replacement on export of xylanase $A$ in Streptomyces lividans. Appl Environ Microbiol 1996, 62:109-114.

48. Ho SN, Hunt HD, Horton RM, Pullen JK, Pease LR: Site-directed mutagenesis by overlap extension using the polymerase chain reaction. Gene 1989, 77:51-59.

49. Zitouni M, Fortin M, Thibeault J-S, Brzezinski R: A dye-labelled soluble substrate for the assay of endo-chitosanase activity. Carbohyd Polym 2010, 80:521-524.

50. Bradford MM: A rapid and sensitive method for the quantitation of microgram quantities of protein utilizing the principle of protein-dye binding. Anal Biochem 1976, 72:248-254.

51. Aretz W, Koller KP, Riess G: Proteolytic enzymes from recombinant Streptomyces lividans TK24. FEMS Microbiol Lett 1989, 65:31-36.

\section{doi:10.1186/1475-2859-10-7}

Cite this article as: Dubeau et al: Modification of genetic regulation of a heterologous chitosanase gene in Streptomyces lividans TK24 leads to chitosanase production in the absence of chitosan. Microbial Cell Factories 2011 10:7.

\section{Submit your next manuscript to BioMed Central and take full advantage of:}

- Convenient online submission

- Thorough peer review

- No space constraints or color figure charges

- Immediate publication on acceptance

- Inclusion in PubMed, CAS, Scopus and Google Scholar

- Research which is freely available for redistribution 